\title{
PENGARUH KOMPETENSI, DUE PROFESSIONAL CARE, INDEPENDENSI, DAN AKUNTABILITAS TERHADAP KUALITAS AUDIT PADA BANK BTN KANTOR WILAYAH KOTA DENPASAR
}

\author{
Ida Ayu Endriyanadewi ${ }^{1}$, I Wayan Rupa ${ }^{2}$, L.G.P. Sri Eka Jayanti ${ }^{3}$ \\ Program Studi Akuntansi \\ Fakultas Ekonomi dan Bisnis Universitas Warmadewa Denpasar, Bali \\ Email: @endriyanadewi@gmail.com
}

\begin{abstract}
ABSTRAK
Penelitian ini bertujuan untuk menjelaskan pengaruh kompetensi, due professional care, independensi, dan akuntabilitas terhadap kualitas audit pada Bank BTN Kantor wilayah Kota Denpasar dengan memakai teknik regresi linier berganda. Populasi pada penelitian ini adalah karyawan Bank BTN Kantor wilayah Kota Denpasar sebanyak 35 karyawan. Jenis data yang digunakan adalah data kuantitatif dengan sumber data primer. Hasil penelitian menggambarkan Kompetensi tidak memberi hasil pengaruh kepada kualitas audit, Due Profesional Care memberi hasil pengaruh positif kepada kualitas audit, Independensi tidak memberi hasil pengaruh kepada kualitas audit, Akuntabilitas memberi hasil pengaruh positif kepada kualiitas audit dimana menggambarkan bahwa semakin tingginya tingkat akuntabilitas maka bentuk pertanggungjawaban kepada kualitas audit akan semakin baik. Hasil penelitian ini diharapkan membantu auditor untuk meningkatkan pengetahuan, kecermatan kepada proses audit dan bersikap netral kepada keputusan yang diambil sehingga kualitas audit dapat meningkat.
\end{abstract}

Kata Kunci: Akuntabilitas, Due Profesional Care, Independensi, Kompetensi, Kualitas audit

\begin{abstract}
This study aims to explain the effect of competence, due professional care, independence, and accountability on audit quality at the BTN Bank of Denpasar City Regional Office by using multiple linear regression techniques. The population in this study were 35 employees of Bank BTN Denpasar City Office. The type of data used is quantitative data with primary data sources. The results of the study illustrate that Competence does not result in an effect on audit quality, Due Professional Care results in a positive effect on audit quality, Independence does not give an effect on audit quality, Accountability results in a positive effect on audit quality which illustrates that the higher level of accountability the form of accountability the quality of the audit will be better. The results of this study are expected to help the auditor to increase knowledge, accuracy of the audit process and be neutral to the decisions taken so that audit quality can be improved.
\end{abstract}


Keywords: Accountability, Due Professional Care, Independence, Competence, Audit quality

\section{A. PENDAHULUAN}

Pihak yang menawarkan jasa keuangan merupakan pihak yang mengerjakan aktivitas jasa finansial pada bidang perbankan, pasar modal, atau indusrti keuangan yang tergolong bukan bank yang diatur dan pihak yang mengawasi adalah dari Otoritas Jasa Keuangan seperti yang disebutkan pada Undang-undang berkaitan dengan Otoritas Jasa Keuangan.perbankan merupakan seluruh hal yang berkaitan dengan bank. Melingkupi lembaga, aktivitas usaha, dan cara termasuk tahapan untuk mengerjakan aktivitas usaha, dan cara juga proses untuk mengerjakan aktivitas usaha dengan cara yang konvensional atau termasuk dengan cara yang berlandaskan prinsip syariah. Adapun pihak yang melakukan aktivitas jasa keuangan secara wajib memakai Akuntan Publik dan Kanotr Akuntan Publik yang sudah ada pada daftar Otoritas Jasa Keuangan dan mempunyai sertifikat kompetensi sejalan dengan kompleksitas usaha pihak yang melakukan aktivtas jasa keuangan yang sudah diatur pada peraturan Otoritas Jasa Keuangan Nomor 13/POJK.03/2017 Pasal 2 berkaitan dengan pemakaian Jasa AKuntan Publk dan Kantor AkuntAn Publik pada aktibitas Jasa Keuangan.

Mathius Tandiontong (2016:172) menyebutkan jika kompetensi berkaitan dengan kemampuan, ilmu, dan pengalaman dari seorang auditor yang tergolong kompeten merupakan auditor yang mempnyai pengetahuan, berpengalaman yang mencukupi supaya bisa berhasil untuk mengerjakan kewajiban auditnya. Due Profesional Care mempunyai dua komponen yang utama yaitu skeptism profesioanl dan tingkat keyakinan yang mencukupi. Pemakaian keahlian secara Profesional dengan cerdas dan tekun memberi tuntutan pada auditr untuk mengambil langkah skeptic Profesional. Tiap individu auditor wajib untuk menjaga profesionalnya berlandaskan prinsip hati-hati dan memiliki kewajiban guna melakukan pertahanan ilmu pengetahuan dan keterampilan dengan cara yang profesional (Abdul Halim, 2015:34).

Independensi merupakan sebuah acuan dari sistem audit yang mendasar guna menyatakan tingkat kredibilitas pelaporan keuangan yang merupakan 
tanggung jawab adari seorang manajemen. Terdapat dua aspek dari independenisasi yaitu 1) independensi nyata dari seorang praktisi ketika melkukan aktivitasnya dan 2) independensi untuk performdari auditor sebagai sebuah komuntas Profesional. Mereka menyebutnya sebagai "independensi praktis" dan “independensi profesi” (Mathius Tandiontong, 2016:169-170).

Mardiasmo (2002:20) menyebutkan jika akuntabilitas merupakan suatu kewajiban dari pihak yng memegang amanat ntuk memberi tanggung jawab, memaparkan, dan memberi pelaporan dan pengungkapan semua aktivitas kegiatan yang meruppakan tanggung jawab kepada pihak yang memberikan amanat dan mempunyai hak dan wewenang untuk menaguh tanggung jawab yang disepakati tersebut. Adapaun yang dimksud dengan kualiitas audit adalah hal yang sangat penting dikarenakan kualitas yang optimal akan bisa melahirkan laporan keuangan dengan tingka kepercayaan yang tinggi sebagai acuan ketika mengambil keputusan. De Angelo (1981) dalam Tjun (2012) menyebutkan jika kualitas dari audit adalah segala jenis peluang jika auditor akan menemui dan memberi laporan mengenai terjadinya pelanggaran kepada sistem akuntansi. Seperti contohnya salah satu BUMN yang memberi gambaran kualiitas audit yang terdapat dlam perbankan pada tangal 6 Mei 2014, OJK menegur BTN berkaitan dengan restrukturisasi kkredit macet yang bermasalah yang tidak mengikuti aturan yang berlaku. OJK dan Bank Indonesia berkaitan dengan tidak dipenuhinya ketetapan hitungan kolektif kredit bermasalah tersebut yang direstrukturisasi.

Banyaknya kasus yang terjadi dalam dunia pengauditan, kualiitas audit menjadi menurun, dan kepercayaan organisasi kepada auditor dalam memeriksa laporan keuangan juga mengalami penurunan, dengan hal tersebut peneliti ingin mengetahui hal yang memberi hasil pengaruh kepada kinerja auditor dalam melakukan pemeriksaan, penilaian, dan pemberian saran kepada organisasi dan ingin mengetahui seberapa besar pengaruh yang peneliti temukan kepada masalah atau kasus-kasus yang sering terjadi termasuk dalam kualiitas audit.

\section{B. TINJAUAN PUSTAKA}

\section{Kompetensi}

Kompetensi merupakan karakteristik dasar dari seorang individu, yang merupakan penyebab terkait kriteria tentang kinerja yang efektif, dan sebagai hal 
tambah dari seorang individu dalam pemahaman, dan kemampuan untuk melakukan suatu pekerjaannya atau profesinya. Menurut Tjun dkk (2012), "kompetensi berkaitan dengan pengetahuan dan pengalaman memadai yang dimiliki akuntan publik dalam bidang auditing dan akuntansi”, dapat disimpulkan bahwa kompetensi bisa dilihat dari segi pengetahuan yang dimiliki seorang auditor untuk mampu mengenali tugas dan tanggungjawabnya, dan pengalaman yang berarti bentuk telah pernah melakukan tugas dan tanggungjawab sebelumnya sehingga mampu melakukan pekerjaannya dan memahami langkah-langkah yang perlu untuk dilakukan

\section{Due Profesional Care}

Singgih dan Bawono (2010) dalam Putri (2013) memberikan definisi mengenai due Profesional care merupakan kecerdasan dan seksamanya dalam memakai keahlian Profesional yang memberi tuntutan untuk mengambil langkah skeptisme Profesional. Seorang auditor wajib untuk mempunyai tingkat keterampilan yang secara umum ada pada seorang auditor dan wajib memakai keterampilan itu dengan cermat dan seksama yang sewajarnya. Oleh karenanya auditor diberi tuntutan untuk mempunyai tingkat keyakinan yang mencukupi gunak melakukan evaluasi bukti audit.

\section{Independensi}

Mengacu pada pendapat dari Tjun dkk (2012), independensi memiliki arti ika seorang akuntan tidak dengan mudh untuk diberi pengaruh dan tidak memihak pada kepentingan dan memiliki kejujuran pada semua pihak yang menaruh kepercayaan kepada pekerjaan seorang akuntan publik. Independensi adaah suatu hal yang amat penting ada pada seorang auditor untuk bekerja sesuai dengan keahliannya. Dimana ketika melaksanakan tugas dan wewenangnya dalam pelaporan wajib untk bebas dari unsur keterikatan semua pihak yang punya urusan pada laporan tersebut, supaya laporan yang dihasilkan bisa dnegan sungguhsungguh jauh dari unsur pemaksaan atau pengaruh dari individu atau pihak lain dan laporan tersebut bisa secara hukum diberi pertannggungjawaban penuh pada auditor dengan tidak ada keterikatan sama sekali.

\section{Akuntabilitas}

Menurut Mardiasmo (2002:20) Akuntabilitas merupakan sebuah kewajiban dari para pihak yang memegang mandat guna memberi tanggung jawab, 
meamaparkan, memberi laporan, dan menjadi pengungkap smua aktivits yang sudah berada pada tanggung jawabnya dengan pihak yang memberikan mandat yang punya kewenangan juga hak untuk mengetahui pertanggungjawaban tersebut. Dapat ditarik simpulan jika akuntabilitas adalah tingkat kepercayaan dari seorang kepada seorang pelaku audit untuk melakukan pemeriksaan dan pelaporan aktivitas kegiatan yang sudah berlangsung pada peruahaan, dan bisa diberi dipenuhi tanggung jawabnya hingga auditor tersebut mempunyai kemampuan untuk memberi laporan tersebut secara penuh pertanggungjawaban.

Hipotesis pada penelitian ini adalah :

$\mathrm{H}_{1}$ : Kompetensi memberi hasil pengaruh positif kepada Kualitas audit pada Bank BTN Kantor wilyah Kota Denpasar

$\mathrm{H}_{2}$ : Due Profesional Care memberi hasil pengaruh positif kepada Kualitas audit pada Bank BTN Kantor wilyah Kota Denpasar

$\mathrm{H}_{3}$ : Independensi memberi hasil pengaruh positif kepada Kualitas audit pada Bank BTN Kantor wilyah Kota Denpasar

$\mathrm{H}_{4}$ : Akuntabilitas memberi hasil pengaruh positif kepada Kualitas audit pada Bank BTN Kantor wilyah Kota Denpasar

\section{METODE PENELITIAN}

\section{Populasi dan Sampel}

Populasi untuk penelitian ini adalah karyawan dari Bank BTN Kntor wilayah Kota Denpasar sebanyak 35 karyawan yang berkaitan. Teknik pengambilan sampel pada penelitian ini adalah metode sensus. Sampel dalam penelitian ini adalah data karyawan pada Bank BTN Kantor wilayah Kota Denpasar sejumlah 35 orang karyawan.

\section{Metode Pengumpulan Data}

Teknik pengumpulan data dalam penelitian ini memakai teknik kuisioner. Selanjutnya kuisioner dibagikan secara langsung dengan pihak-pihak terkait.

\section{Metode Analisis Data}

Analisis Regresi Linear Berganda

Menurut Somantari (2016:243) analisis regresi linear berganda adalah alat statiatik yang dipakai guna mencari tahu pengaruh diantara satu atau sejumlah variabel kepada satu buah variabel. Analisis regresi linear berganda ini dihitung 
memakai bantuan aplikasi SPSS. Untuk rumus regresi berganda sebagai berikut:

$$
Y=a+b_{1} X_{1}+b_{2} X_{2}+b_{3} X_{3}+b_{4} X_{4}+e
$$

\section{HASIL DAN PEMBAHASAN}

Analisis Regresi Linier Berganda

Tabel 1

Hasil Uji Analisis Regresi Linier Berganda

\begin{tabular}{|ll|r|r|r|}
\hline \multirow{2}{*}{ Model } & \multicolumn{2}{|c|}{$\begin{array}{c}\text { Unstandardized } \\
\text { Coefficients }\end{array}$} & $\begin{array}{c}\text { Standardized } \\
\text { Coefficients }\end{array}$ \\
\cline { 3 - 5 } & & \multicolumn{1}{|c|}{ B } & Std. Error & \multicolumn{2}{c|}{ Beta } \\
\hline 1 & (Constant) & 5.238 & 3.502 & \\
& X1 & .058 & .099 & .085 \\
& X2 & -.301 & .146 & -.310 \\
& X3 & .159 & .101 & .213 \\
& X4 & .868 & .144 & .763 \\
\hline
\end{tabular}

a. Dependent Variable: $Y$

$$
\mathrm{Y}=0,085 \mathrm{X}_{1}-0,310 \mathrm{X}_{2}+0,213 \mathrm{X}_{3}+0,763 \mathrm{X}_{4}
$$

Dari persamaan analisis regresi linier berganda diatas dapat dijelaskan sebagai berikut :

a. Kompetensi (X1) mempunyai koefisien regresi posiitif bernilai 0,085 artinya apabila kompetensi mengalami peningkatan maka kualiitas audit akan mengalami kenaikan.

b. Due Profesional Care (X2) mempunyai koefisien negatif bernilai $-0,310$ artinya apabila due prosessional care mengalami peningkatan maka kualiitas audit mengalami penurunan.

c. Independensi (X3) mempunyai koefisien regresi posiitif bernilai 0,213 artinya apabila independensi mengalami peningkatan maka kualiitas audit mengalami kenaikan.

d. Akuntabilitas (X4) mempunyai koefisien regresi posiitif bernilai 0,763 artinya apabila akuntabilitas mengalami peningkatan maka kualiitas audit mengalami kenaikan. 


\section{Uji Hipotesis (Uji t)}

Tabel 2

Hasil Uji Hipotesis (Uji t)

\begin{tabular}{|l|c|c|}
\hline \multicolumn{1}{|c|}{ Model } & T & Sig. \\
\hline Constant & 1,496 & 0,145 \\
Kompetensi & 0,591 & 0,559 \\
Due Profesional Care & $-2,086$ & 0,047 \\
Independensi & 1,576 & 0,125 \\
Akuntabilitas & 6,011 & 0,000 \\
\hline
\end{tabular}

Sumber : Data diolah, 2020 (Lampiran 3)

Mengacu pada hasil uji hipotesis (Uji t) maka dapat dijelaskan signifkansi antara variabel bebas Kompetensi (X1), Due Profesional Care (X2), Independensi (X3), dan Akuntabilitas (X4) kepada variabel terikat Kualiitas audit sebagai berikut :

a. Pengaruh Kompetensi kepada Kualiitas audit.

Hasil uji hipotesis (uji t) menggambarkan t hitung bernilai 0,591 dan signifkansi bernilai 0,559>0,05 artinya variabel kompetensi dinyatakan memberi hasil pengaruh tidak signifkan kepada kualiitas audit. Sehingga $\mathrm{H}$ 1 dilakukan penolakan.

b. Pengaruh Due Profesional Care kepada Kualiitas audit.

Hasil uji hipotesis (uji t) menggambarkan t hitung bernilai -2,068 dan signifkansi bernilai $0,047<0,05$ artinya variabel due Profesional care dinyatakan memberi hasil pengaruh signifkan kepada kualiitas audit. Sehingga H2 diberi penerimaan.

c. Pengaruh Independensi kepada Kualiitas audit.

Hasil uji hipotesis (uji t) menggambarkan t hitung bernilai 1,576 dan signifkansi bernilai 0,125 > 0,05 artinya variabel independensi dinyatakan memberi hasil pengaruh tidak signifkan kepada kualiitas audit. Sehingga H3 dilakukan penolakan.

d. Pengaruh Akuntabilitas kepada Kualiitas audit.

Hasil uji hipotesis (uji t) menggambarkan t hitung 6,011 dan signifkansi bernilai $0,000<0,05$ artinya variabel akuntabilitas dinyatakan memberi hasil pengaruh signifkan kepada kualiitas audit. Sehingga hipotesis 4 
diberi penerimaan.

Pembahasan pada penelitian ini adalah :

1. Pengaruh Kompetensi kepada Kualiitas audit pada Bank BTN Kntor wilayah Kota Denpasar

Hasil uji hipotesis (uji t) menggambarkan t hitung bernilai 0,591 dan signifkansi bernilai 0,559>0,05 artinya variabel kompetensi dinyatakan memberi hasil pengaruh tidak signifkan kepada kualiitas audit. Hasil yang sama didapatkan oleh Setyogati (2018) yang menyatakan kompetensi tidak memberi hasil pengaruh kepada kualiitas audit, berbeda dengan penelitian Al-Hara (2018), Alam (2017), Aziz (2018), dan Siddiqi (2017) yang menyatakan bahwa kompetensi memberi hasil pengaruh posiitif kepada kualiitas audit.

2. Pengaruh Due Profesional Care kepada Kualiitas audit pada Bank BTN Kntor wilayah Kota Denpasar

Hasil uji hipotesis (uji t) menggambarkan t hitung bernilai -2,068 dan signifkansi bernilai $0,047<0,05$ artinya variabel due Profesional care dinyatakan memberi hasil pengaruh signifkan kepada kualiitas audit. Hasil yang sama didapatkan oleh Febriyanti R (2014), Setyogati G (2018), dan Alam (2017) yang menyatakan due Profesional care memberi hasil pengaruh kepada kualiitas audit, berbeda dengan penelitian Al-Hara (2018) yang menyatakan bahwa due Profesional care tidak memberi hasil pengaruh kepada kualiitas audit.

3. Pengaruh Independensi kepada Kualiitas audit pada Bank BTN Kntor wilayah Kota Denpasar

Hasil uji hipotesis (uji t) menggambarkan t hitung bernilai 1,576 dan signifkansi bernilai $0,125>0,05$ artinya variabel independensi dinyatakan memberi hasil pengaruh tidak signifkan kepada kualiitas audit. Hasil yang sama didapatkan oleh Febriyanti R (2014) dan Al-Hara (2018) yang menyatakan Independensi tidak memberi hasil pengaruh kepada kualiitas audit, berbeda dengan penelitian Aziz (2018) dan Alam (2017) yang menggambarkan bahwa Independensi memberi hasil pengaruh kepada Kualiitas audit.

4. Pengaruh Akuntabilitas kepada Kualiitas audit pada Bank BTN Kntor wilayah Kota Denpasar

Hasil uji hipotesis (uji t) menggambarkan t hitung 6,011 dan signifkansi bernilai $0,000<0,05$ artinya variabel akuntabilitas dinyatakan memberi hasil 
pengaruh signifkan kepada kualiitas audit. Hasil yang sama didapatkan oleh Alam (2017) dan Aziz (2018) menggambarkan bahwa akuntabilitas memberi hasil pengaruh kepada kualiitas audit, berbeda dengan penelitian Febriyanti R (2014) yang menyatakan akuntabilitas tidak memberi hasil pengaruh kepada kualiitas audit.

\section{E. PENUTUP}

\section{Simpulan}

a. Kompetensi tidak memberi pengaruh kepada kualitas audit pada Bank BTN Kntor wilayah Kota Denpasar.

b. Due Profesional Care memberi pengaruh positif kepada kualitas audit pada Bank BTN Kntor wilayah Kota Denpasar.

c. Independensi tidak memberi pengaruh kepada kualitas audit pada Bank BTN Kntor wilayah Kota Denpasar.

d. Akuntabilitas memberi pengaruh positif kepada kualitas audit pada Bank BTN Kantor wilayah Kota Denpasar.

\section{Saran}

a. Kompetensi sangat mendukung seorang auditor dalam menyelesaikan tugasnya dengan baik dan berkualitas.

b. Due Profesional Care harus diperhatikan oleh setiap auditor

c. Akuntabilitas sangat penting untuk dimiliki seorang auditor.

\section{DAFTAR PUSTAKA}

Agusti,Resu., \& Pertiwi,Nstia, Putri.(2013).Pengaruh Kompetensi indepndensi, dan Professionlisme Terhadap Kalitas Audit.Journal Ekonomi Vol. 21.Nomor 3 September.

Alam D.(2017). Pegaruh Kompetensi,Independensi, Akuntanbilitas,dan Due Profesional Care pada Kualitas Audit. E-jurnal Akuntansi Universitas Udayana.Vol.21.3.Desember(2017):2282-2310.

Aziz, A (2018). Pengaruh Akuntabilitas,Kompetensi, dan Independensi Auditor Kepada Kualiitas audit pada Kantor Akuntan Publik di Surabaya E-jurnal EkonomiUniversitas islam majapahit Mojokerto Vol.1,Nomor 1 Maret 2018. 
Febriyanti,R. (2014).Pengaruh Independensi,Due Profesional Care, dan Akuntanbilita Kepada Kualiitas audit(Studi Epiris padaKantorAkuntan Publik diKota Padangdan Pekanbaru). Artikel Fakultas Ekonomi: Universitas Negeri Padang.

Mardiasmo 202) Akntansi SektorPublik .Penerbit Andi.Yogykarta.

Mathius Tandiontong, (2016),Kualiitas audit dan Pengukurannya,Penerbit Alfabeta,Bandung

Siddiqi, M.,F. (2017).Pengaruh Tingkat Pendidikan, Kompetensi, Motivasi Fee, Profesionalisme dan Pengalaman Audit kepada Kualiitas audit (Studi Empiris pada Kantor Akuntan Publik diMalang). Skripsi. Jurusan Akuntansi,FakultasEkonomi.Universitas IslamNegeri.

Singgih,Elisha, Muliani.,\& Bawono,Icuk,Rangga.(2010).Pengaruh Independensi, Pengalaman,Due Profesional Care, dan Akuntabilitas Kepada Kualiitas audit.Simposium NasionalAkuntansiXIII urwokerto.

Sugiyono.2015.MetodePenelitian, Penerbit Gramedia, Jakarta.

Tjun,Lauw, Tjun.,Marpaung,Elyzabet, Indrawati.,Setiawan, Santi.(2012). Pengaruh Kompetensi dan Independensi Auditor Kepada Kualiitas audit. Journal.Akuntansi Vol.4No.1Mei 201233-5 